\title{
Potentiometric ion- and bioselective electrodes based on asymmetric polyurethane membranes
}

\author{
Dong Liu and Mark E Meyerhoff \\ Department of Chemistry, Unwerstty of Michigan, Ann Arbor, MI 48109 (USA)
}

Howard D Goldberg and Richard B Brown

Department of Electncal Engineerng and Computer Science, Universtty of Michigan, Ann Arbor, MI 48109 (USA)

(Received 13th May 1992, revised manuscript received 14th September 1992)

\begin{abstract}
The potentiometric ion responses of ammonium- and proton-selective electrodes prepared by incorporating appropriate neutral carriers within novel asymmetric polyurethane membranes are reported The membranes are formed by first casting a plasticized polyurethane(PU)/terpoly(vnnyl chlonide/vinyl acetate/vinyl alcohol) (PVA)based Ion-selective membrane and then applying a thin second layer of a more hydrophilic polyurethane (HPU) containing polylysine The resultıng asymmetric membranes function equivalently to normal PU/PVA membranes and conventional poly(vinyl chloride) type membranes in terms of potentiometric 1on selectivity and dynamic response properties The large amount of amine functional groups from the polylysine within the outer hydrophilic layer can be further activated for direct enzyme immobilization As examples, adenosine deaminase and urease are immobilized on ammonium- and proton-selective membranes, respectively, to yield adenosine and urea electrodes with good dynamic responses and sensitivities Advantageous use of this new membrane system for preparation of solid-state microfabricated enzyme-based sensors is also described
\end{abstract}

Keywords Biosensors, Ion-selective electrodes, Potentiometry, Asymmetric membranes, Polyurethane membranes, Solid-state electrodes

Over the last three decades, a variety of bioselective electrodes have been developed using potentiometric gas- and ion-selective membranes as transduction elements [1-4] Appropriate bioreagents (such as enzymes, antibodies, bioreceptors, cells and tissues) are immobilized on such transducers in a manner that enables the detection of the product of the corresponding biological reaction in a thin layer of solution adjacent to the electrode's surface Immobilization methods used include entrapment withın a crosslınked polymer

Correspondence to M E Meyerhoff, Department of Chemistry, University of Michigan, Ann Arbor, MI 48109 (USA) matrix, physical adsorption and covalent attachment through bifunctional crosslınking reagents [5] Use of simple polymer membrane type ionselective electrodes [6-10] (e g , ammonium, carbonate, $\mathrm{pH}$ ) as the base sensing elements has the advantage of providing biosensors that are easy to fabricate and exhibit rapid response tımes In principle, potentiometric biodetection schemes based on these transducers can also be combined with the modern silicon technology to make small, multısensing and disposable solıd-state biosensors [11-15] that could serve as flow-through biodetectors, or single-use biosensing devices While lack of selectivity over endogenous ions in real 
samples has been a problem with ion-selective electrode-based biosensors [7], a variety of new approaches to elımınate these interferences, particularly in flow-through detection systems, have been introduced recently with considerable success [16-18]

Traditionally, enzymes have been deposited on conventıonal poly(vinyl chloride) (PVC) type ionselectıve membranes via glutaraldehyde crosslınking reactions, etc [2,5] Such Immobilızed proteın layers, however, generally have poor adhesion to the very hydrophobic surface of the plasticized PVC membrane While modification of the membranes such as using functionalized polymers ( $\mathrm{g}$, aminated or carboxylated PVC) has been attempted to covalently attach or adsorb the bioreagents to the hydrophobic PVC membranes $[10,19,20]$, the number of avallable functional groups for such purposes is often quite low, yielding biosensors with poor bioreagent loading factors

The problem of efficiently attaching enzymes and other bioreagents to polymer membrane electrode surfaces has been addressed previously by Cha and Meyerhoff [9], who developed novel asymmetric cellulose acetate type 1on-selective membranes for such purposes These membranes, while useful for preparing conventional electrodes in which the membrane is mounted between the sample and inner reference electrolyte solutions, are not suitable for preparation of solid-state (or solid-contact) type probes This is because the more hydrophilic outer cellulose acetate film used for enzyme immobilization must be coated from the back side with appropriate plasticizer/ionophore/cellulose acetate cocktail to render the resulting dual layer films ion responsive Although Gotoh et al [12] have suggested the use of poly(vinyl butyral) (PVB) membranes to prepare micro-field effect transistor based solıd-state biosensors, such PVB films served only as a matrix for the immobilized enzymes and did not need to exhıbit electrochemıcal response and selectivity toward given ions This is because the underlying metal oxide gate of the FET was used as an effective pH transducer to monitor $\mathrm{pH}$ changes arising from the enzyme reactions within the PVB layer
In this paper a new type of asymmetric ionselective membrane is described which is potentially more useful for fabrication of solid-state type potentiometric biosensors The proposed membrane system consists of a very thin hydrophilic polyurethane (HPU) membrane possessing a high density of amıne functional groups (in the form of polylysine) that is coated and fused to an underlying more hydrophobic plasticized polyurethane (PU)/poly(vınyl chloride/ vinyl acetate/vinyl alcohol) (PVA) membrane containing the appropriate ion carrier The potentiometric response of the asymmetric polyurethane membranes is shown to be essentially the same as the base ion-selective membrane (PU/PVA) and the large amount of functional groups within the outer hydrophilıc film can be used for the covalent attachment of bioreagents to the membrane's surface Since the underlying PU/PVA ion-selective film has been shown previously to adhere very tightly to silicon dioxide and silicon nitride surfaces [21], the new asymmetric membrane system is well suited for fabrication of solıd-state biosensor devices Indeed, the performance of both conventional and solidstate potentıometric enzyme electrodes prepared with this asymmetric membrane system is presented below using urea and adenosine as model analytes It should be noted that although polyurethane matrices have been used previously as solıd-phases for enzyme and protein immobilization [22,23], in such systems, the polyurethanes were never an integral part of a signal transducer, as is reported herein

\section{EXPERIMENTAL}

\section{Apparatus}

For preparation and testıng of conventional sensor designs, the asymmetric membranes with and without immobilized enzymes were mounted in Philıps electrode bodies (IS-561) (Glasblasereı Moller, Zurich) The external reference electrode was a double-junction $\mathrm{Ag} / \mathrm{AgCl}$ Fisher electrode The potentiometric measurements of the ionselective electrodes were monitored through a high impedance amplifier to a Zenith Z-100 PC 
computer equipped with a Data Translation A/D converter system (DT2801)

Gel permeation chromatography (GPC) on a Waters ALC 200 system (Milford, MA) was used to determine the molecular weight of the hydrophilic polyurethane The effluent (in THF) was monitored by a differential refractometer (R401) and the retention time of the sample through a series of three $\mu$ Styragel columns of pore size $500,10^{3}$ and $10^{4} \AA$ was used for the calculation of molecular weight based on prior calibration with narrow molecular weight polystyrene standards

\section{Reagents}

Tecoflex polyurethane (PU) (SG-80A) was obtained from Thermedics (Woburn, MA) The terpolymer, poly(vinyl chlonde/vinyl acetate/vinyl alcohol) (80 $515 \mathrm{wt} \%$, MW 40000) was a product of Scientific Polymer Products (Ontarıo, NY) Nonactın, bıs(2-ethylhexyl) sebacate (DOS), bis(2-ethylhexyl) adipate (DOA) and potassium tetrakıs(4-chlorophenyl) borate (KTpCIPB) were purchased from Fluka (Ronkonkoma, NY) Adenosine, adenosine deaminase (ADA, Type VII, from calf intestınal mucosa), urease (type VII, from Jack Beans), glutaraldehyde and polylysine (PLS) (hydrobromide, MW 30000-70000) were obtained from Sigma (St Louls, MO) Tr1dodecylamine (TDDA) was obtained from Eastman Kodak (Rochester, NY) and silicon(IV) tetrachloride $\left(\mathrm{SiCl}_{4}, 10 \mathrm{M}\right.$ solution in dichloromethane) was from Aldrich (Milwaukee, WI) The hydrophilıc PU (HPU) (40\% water uptake) was a gift from Mr Peter Burleigh, Mallınckrodt Sensor Systems (Ann Arbor, MI) It was prepared according to the procedure outlined in Ref 24

All other chemicals were of analytical-reagent grade All standard solutions and buffers were prepared with reverse osmosis/deionized water

\section{Preparation of asymmetrc ton-selective mem- branes}

Figure 1 shows a schematic diagram of the asymmetric polyurethane membrane, depicted in this case with an enzyme layer attached to the polylysine incorporated within the outer HPU film

The basic underlying ion-selective membrane was composed of 33 wt \% of PU/PVA (80 wt \% of PU and $20 \mathrm{wt} \%$ of PVA), $66 \mathrm{wt} \%$ of plast1cizer and 1 wt \% of ionophore For ammonium con-selective membranes, DOA was used as plasticizer and nonactin as the ionophore For proton-selective membranes, DOS and TDDA served as the plasticizer and $\mathrm{pH}$ ionophore [25], respectively, and KTpCIPB at $1 \mathrm{wt} \%$ was also added to the membrane casting solution All of the membrane components (total mass $=200 \mathrm{mg}$ ) were dissolved in THF and cast into a $22 \mathrm{~mm}$ (i d) glass ring placed on a glass plate The THF solvent was allowed to evaporate overnight before further coatıng with the outer HPU/PLS layer

The second layer of the asymmetric membrane was prepared by first treatıng the surface of the

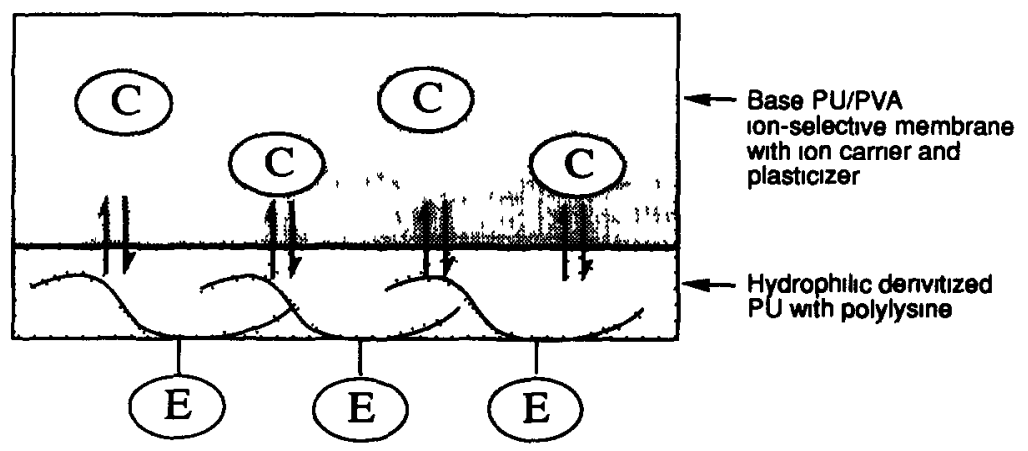

Fig 1 Schematic diagram of the asymmetric polyurethane-based ion-selective membrane configured with immobilized enzyme layer $\mathrm{C}$, ion carrier, $\mathrm{E}$, enzyme 
base PU/PVA ion-selective membrane with 150 $\mu 1$ of $002 \mathrm{M} \mathrm{SiCl}_{4}$ (in $\mathrm{CH}_{2} \mathrm{Cl}_{2}$ ) for 2-3 min Then, $1 \mathrm{mg}$ of PLS with $10 \mathrm{mg}$ of HPU in a mixed solvent $(250 \mu \mathrm{l}$ of methyl alcohol and $50 \mu \mathrm{l}$ of THF) was applied on top of the base PU/PVA membrane Several hours were required for the outer film to cure In the case of proton-selective asymmetric membranes, only $1 \mathrm{mg}$ of PLS and 5 mg of HPU in the same amount of mixed solvent were applied to the surface of the base PU/PVA membrane

Electrodes were prepared by punching small disks from the above membranes and mounting them in the Philips electrode body with HPU/ PLS layer facing out toward the sample side The internal reference electrolyte was $01 \mathrm{M}$ of $\mathrm{NH}_{4} \mathrm{Cl}$ for $\mathrm{NH}_{4}^{+}$-selective electrodes and $002 \mathrm{M}$ $\mathrm{NaH}_{2} \mathrm{PO}_{4}-003 \mathrm{M} \mathrm{Na}_{2} \mathrm{HPO}_{4}-0015 \mathrm{M} \mathrm{NaCl}, \mathrm{pH}$ 70 , for the proton-selective electrodes All potentiometric measurements were made at room temperature with a sample volume of $100 \mathrm{ml}$

Immobulization of adenosine deaminase / urease on the asymmetric ion-selective membranes

Adenosine deaminase and urease were attached to the surface of the asymmetric membranes using the glutaraldehyde crosslinking method described in Ref 9 with minor modifications For the two-step glutaraldehyde method, the asymmetric lon-selective membrane mounted in the electrode body was immersed in $25 \%$ of glutaraldehyde solution for $5 \mathrm{~min}$ After brief washing of the membrane with cold water, $10 \mu \mathrm{l}$ of ADA (19 units) or urease (286 units) (prepared by dissolving $05 \mathrm{mg}$ ADA/urease in $10 \mu \mathrm{l}$ of $005 \mathrm{M}$ phosphate buffer, $\mathrm{pH} 70$ ) was applied onto the outer surface of the membrane (surface area of $126 \mathrm{~mm}^{2}$ )

For the one-step glutaraldehyde method, 35 $\mu \mathrm{l}$ of glutaraldehyde and $10 \mu \mathrm{l}$ of enzyme solutıon were sequentially applied on the surface of the asymmetric membrane mounted within the electrode body The coupling reaction was allowed to proceed for $12 \mathrm{~h}$ at $4^{\circ} \mathrm{C}$ The membrane was then washed with Tris- $\mathrm{HCl}$ buffer $(005 \mathrm{M}$, pH 72 ) and stored in buffer at $4^{\circ} \mathrm{C}$ before use
Evaluating potentrometnc responses of conventional ton- and bloselective electrodes

The potentiometric responses of $\mathrm{NH}_{4}^{+} / \mathrm{H}^{+}-$ selective electrodes and the corresponding ADA/ urease enzyme electrodes were evaluated by addition of standard solutions of inorganic salt or adenosine/urea into $100 \mathrm{ml}$ of well stirred buffer solution at room temperature The background electrolyte used depended on the cons and substrates being examined ( $005 \mathrm{M}$ Tris- $\mathrm{HCl}$, pH 72 , for $\mathrm{NH}_{4}^{+}$, adenosine, and urea response with $\mathrm{NH}_{4}^{+}$-selective membrane electrodes, 114 $\mathrm{mM}$ boric acid-67 $\mathrm{mM}$ citric acid-10 $\mathrm{mM}$ $\mathrm{NaH}_{2} \mathrm{PO}_{4}$ for $\mathrm{pH}$ response, and $0001 \mathrm{M}$ Tris$\mathrm{HCl}-01 \mathrm{M} \mathrm{NaCl}, \mathrm{pH} 7 \mathrm{0}$, for urea response with $\mathrm{H}^{+}$-selective membrane) For evaluating the $\mathrm{pH}$ response of the TDDA-doped membranes, the $\mathrm{pH}$ of the borıc acid/citric acid/phosphate universal buffer was varied by addition of either $\mathrm{NaOH}$ or $\mathrm{HCl}$ while simultaneously measuring the $\mathrm{pH}$ of the solution with a calibrated glass electrode For the ammonium-selective membranes, ion selectivity coefficient data were obtained by the separate solution method [26]

\section{Preparation of solid-state enzyme electrodes}

The solid-state biosensor design examined in these studies is illustrated in Fig 2 Aluminum conductor leads were patterned on slicon wafers, and insulated (except at the sensing site) with silicon nitride using standard microelectronic fabrication procedures A layer of silver epoxy was

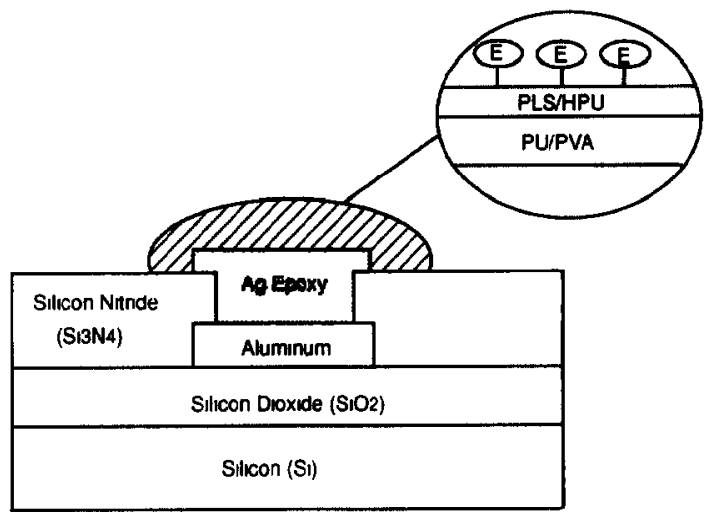

Fig 2 Side view of the solid-state biosensor fabricated with asymmetric polyurethane membrane 
then screen printed over the exposed aluminum at the sensing site $A$ thin (100-300 $\mu \mathrm{m})$ layer of the plasticized PU/PVA polymer casting solution containing either TDDA or nonactin was then cast onto the silver epoxy layer This membrane adhered tightly to the silver epoxy and the surrounding silicon nitride coating of the wafer $A$ very thin layer of HPU containing polylysine was then coated over the ion-selective layer using a $\mathrm{SiCl}_{4}$ pretreatment step as described above for the regular asymmetric membranes Urcase and adenosine deaminase were then immobilized by the one- or two-step glutaraldehyde procedures outlined above

\section{RESULTS AND DISCUSSION}

\section{Characterization of asymmetric membranes}

A key component of the asymmetric ion-selective membrane system is the outer hydrophilic polyurethane (HPU) material which can be loaded with polylysine for subsequent bioreagent immobilization This membrane must be hydrophilic enough to readily pass ions liberated from any biocatalytic reaction occurring at the surface Preliminary characterization of the HPU film consisted of measuring its water uptake as well as determining its elemental composition $(\mathrm{C}, \mathrm{H}$ and $\mathrm{N}$ analysis) and molecular weight (by GPC), and comparing these values to the supposedly more hydrophobic Tecoflex material which comprises 80 wt \% of the polymer material used to formulate the underlying ion-selective layer The average molecular weight of the HPU material was found to be 45000 , which is much lower than that found for the hydrophobic polyurethane (MW 190000) Water uptake experuments indicated that the HPU material absorbs water to a far greater extent than the hydrophobic Tecoflex material (40 wt \% vs $1 \mathrm{wt} \%$ ) Elemental analysis of the two polymers yielded the following results $\mathrm{C}$ $6648 \%, \mathrm{H} 11$ 13\%, N $229 \%$ for the hydrophobic Tecoflex polyurethane, C $6130 \%$, H $999 \%$, N $370 \%$ for the HPU This elemental analysis data correlates with the fact that more disocyanate reagent, and thus more urethane linkages are present within the HPU polymer and this leads to

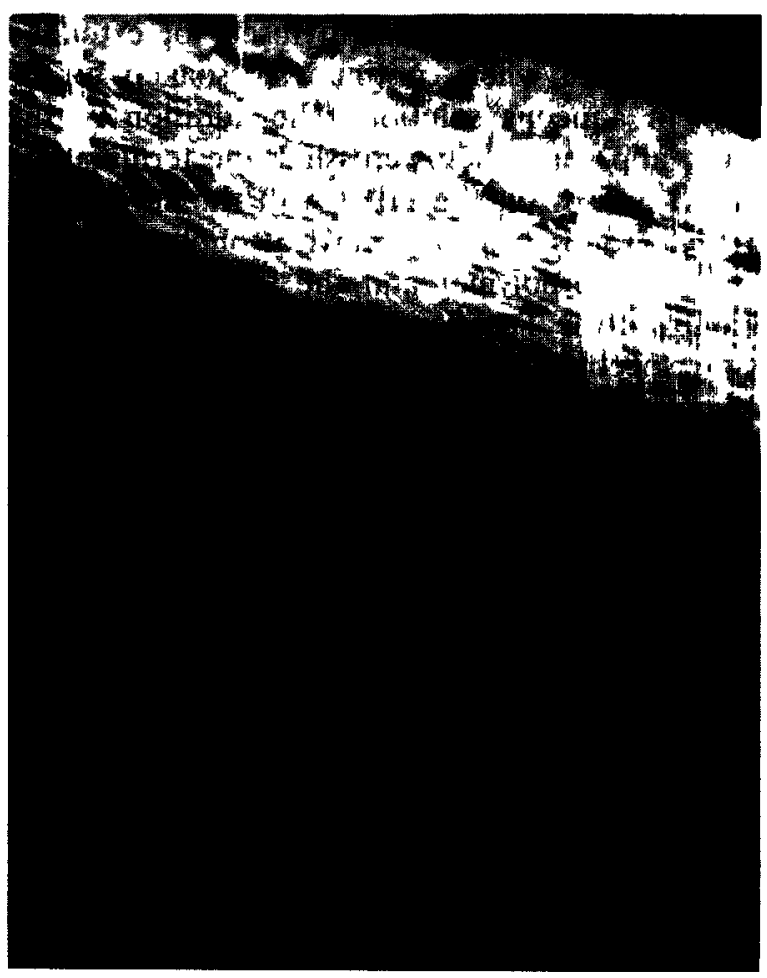

Fig 3 Scanning electron micrograph of the cross-section of an asymmetric ion-selective polyurethane membrane

a more hydrophilic polymer with enhanced water uptake [24]

A scanning electron micrograph of the crosssection of a dry asymmetric ion-selective polyurethane membrane is shown in Fig 3 The thicker layer is the plasticized PU/PVA ionselective membrane (approximately $300 \mu \mathrm{m}$ in thickness), while the upper thin layer is formed from the HPU mixed with polylysine (HPU/PLS) (approximately $9 \mu \mathrm{m}$ in thickness) It can be seen that the textures of two layers are quite different The hydrophobic plasticized bulk layer is more dense while the upper layer appears somewhat porous, apparently due to its more hydrophilic character

The adhesion of the hydrophilic HPU/PLS layer to the underlying hydrophobic PU/PVA membrane is greatly enhanced by applyıng 002 $\mathrm{M}$ of $\mathrm{SiCl}_{4}$ to the surface of the thicker PU/PVA layer containing the ion-selective reagents $(\mathrm{e} g$, nonactın or TDDA) Indeed, using this proce- 
dure, the two layers remain fused for extended periods even when continuously soaked for 30 days in aqueous solution The addition of the $\mathrm{SiCl}_{4}$ apparently helps crosslink the terminal hydroxyl groups on the HPU with the surface hydroxyl groups from the vinyl alcohol portion of the PVA terpolymer and the terminal hydroxyl groups of the Tecoflex PU An energy dispersive $x$-ray spectrum (EDS) of the cross-section of the asymmetric polyurethane membrane suggests that the $\mathrm{SiCl}_{4}$ is mostly distributed at the interface of the two layers and penetrates into the underlying bulk 1on-selective membrane to a depth of about $10 \mu \mathrm{m}$ Only low intensity $\mathrm{S}_{1}$ or $\mathrm{Cl}$ bands were observed near the surface of the asymmetric HPU/PLS membrane, suggesting that the amine groups of the polylysine at the surface are not greatly affected by the added $\mathrm{SiCl}_{4}$ and are free to be used for enzyme immobilization

It is believed that the potentiometric ion response of the asymmetric membrane occurs at the interface of the HPU layer and the plast1cized PU/PVA film That 1s, the HPU/polylysine layer acts as a thin hydrophilic sponge in which ions readily move up to the hydrophobic PU/PVA/ 1onophore film where they participate in an equilibrium phase extraction creating the interfacial charge separation or phase boundary potential [27] which changes as a function of ion activities

The ability of the outer HPU film to retain the added polylysine after prolonged exposure to aqueous solution was also investigated Since the polylysine is not chemically attached to the outer HPU, it was initially thought that this very hydrophilıc cationic material would leach out quickly with time To investigate this possibility, the outer surface of the asymmetric membranes was treated with trinitrobenzenesulfonate (TNBS), a reagent that reacts rapidly with the primary amine groups of polylysine to yield a color change from yellow to orange-red [28] This test was carried out both before and after extended soakıng and washing sequences It was found that the degree of color formation did not change appreciably even after repeatedly soakıng the membranes in $\mathrm{Tris}-\mathrm{HCl}$ buffer solution for 7 days, with frequent changes of the buffer each day ( 5 times per day) Thus, it

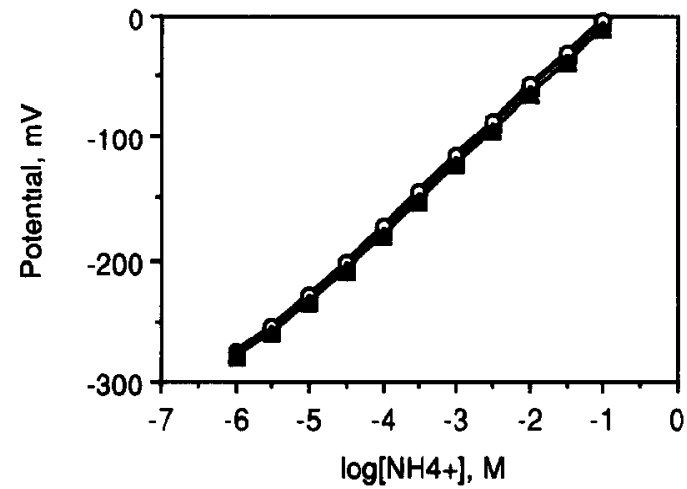

Fig 4 Potentiometric response of ammonium-selective membranes doped with nonactin (口) PVC membrane, (O) PU/PVA membrane, ( $\triangle$ ) PU/PVA-HPU/PLS asymmetrıc membrane

appears that the polylysine is well entrapped/ entangled within the hydrophilic polyurethane membrane and reactive amine groups remain at the surface for extend periods of tıme It should be noted that polylysine has been used previously for the non-covalent immobilization of anionic charged biomolecules, such as heparın, by takıng advantage of its polycationic character to yield strong charge-charge interaction [29] However, the amine groups of anchored polylysine can also be used for covalent enzyme immobilization via classıcal crosslınkıng agents (e g , glutaraldehyde) Since the covalent binding is irreversible, more stable immobilization can be achieved

Potentiometric ion response and selectivity of the asymmetric membranes

Before using the asymmetric membranes to prepare biosensors, it is important to document that such membranes do indeed respond potentiometrically to 1ons, and with response characteristics and selectivities nearly equivalent to conventional polymer membrane ISEs Figure 4 illustrates the typical equilibrium potentiometric responses observed toward ammonium ions in a Tris- $\mathrm{HCl}$ buffer background electrolyte for electrodes fabricated with an asymmetric membrane, a plain PU/PVA membrane (no outer HPU/PLS layer), and a conventional PVC membrane, all containing nonactin as the membrane active ionophore As shown, the potentiometric re- 


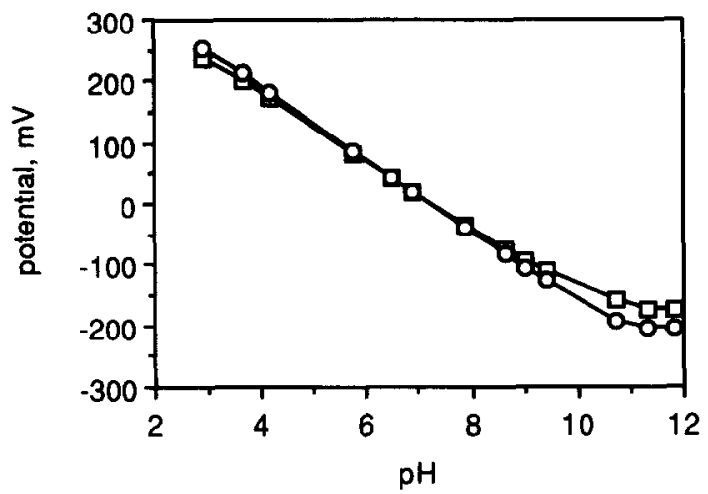

Fig 5 Potentiometric pH response of TDDA-doped polyurethane membranes (O) PU/PVA membrane, () PU/ PVA-HPU/PLS asymmetric membrane

sponse toward ammonium ions, in terms of slope (typically $56 \mathrm{mV} /$ decade in the range of $10^{-5}$ to $10^{-1} \mathrm{M}$ of $\mathrm{NH}_{4}^{+}$) and detection limits, is essentially equivalent for the three different membranes Response tımes were also quite similar (typically withın $10 \mathrm{~s}$ ), indicatıng that the diffusion of ammonium lons through the outer HPU/ PLS thin film is rather rapid, at least relative to 1on-extraction reactions at the PU/PVA/1onophore-HPU interface

Figure 5 shows the potentiometric $\mathrm{pH}$ response of TDDA-doped asymmetric and plain PU/PVA membranes As can be seen, the add1tion of the HPU/polylysine outer layer does not affect significantly the response to protons Typ1cally, slopes of $57 \mathrm{mV} / \mathrm{pH}$ are observed for the asymmetric membranes in the pH range of 3-10 Again, no noticeable elongation in response time is observed when comparing the dynamic $\mathrm{pH}$ response of the asymmetric membranes to plain
PU/PVA films doped with TDDA It should be noted that these equivalent responses can only be achieved by reducing by one-half of the amount of polylysine loaded into the outer HPU layer (compared to the ammonium-selective membrane system)

To determine whether the presence of the outer HPU layer alone, or an outer HPU/PLS layer influences ion selectivities, the selectivity coefficients of the ammonium membranes were determıned via the separate solution method As shown in Table 1 , for the most part, little difference in ammonium ion selectivity is observed for the asymmetric ammonium membranes (PU/ PVA-HPU/PLS) when compared to plain PU/ PVA, PU/PVA coated with HPU (no polylysinc) (PU/PVA-HPU) and conventional PVC membranes Some increased response to protons is observed, although practical selectivity for measurements of ammonium at or near neutral $\mathrm{pH}$ values is still quite acceptable

Conventional biosensors based on the asymmetnc ton-selectuve membranes

Urease and adenosine deaminase served as model enzyme systems to examine the utility of using the asymmetric polyurethane-based membranes for preparation of potentiometric biosensors These enzymes were coupled to the surfaces of $\mathrm{pH}$ and ammonium-selective asymmetric membranes, respectively Adenosine deamınase catalyzes the following reaction

Adenosine $+\mathrm{H}_{2} \mathrm{O} \rightarrow$ Inosine $+\mathrm{NH}_{4}^{+}$

Urease catalyzes the hydrolysis of urea as follows $\left(\mathrm{NH}_{2}\right)_{2} \mathrm{CO}+2 \mathrm{H}_{2} \mathrm{O}+\mathrm{H}^{+} \rightarrow 2 \mathrm{NH}_{4}^{+}+\mathrm{HCO}_{3}^{-}$

\section{TABLE 1}

Selectivity coefficients of nonactın-based membranes prepared with varıous polyurethane matrices

\begin{tabular}{|c|c|c|c|c|c|c|c|}
\hline \multirow[t]{2}{*}{ Membrane matrux } & \multicolumn{7}{|c|}{$\log K_{\mathrm{NH}_{4}^{+},{ }^{\text {por }}}{ }^{a}$} \\
\hline & $\mathrm{Li}^{+}$ & $\mathrm{Na}^{+}$ & $\mathbf{K}^{+}$ & $\mathbf{M g}^{2+}$ & $\mathrm{Ca}^{2+}$ & $\mathrm{Me}_{4} \mathrm{~N}^{+}$ & $\mathbf{H}^{+}$ \\
\hline PU/PVA & -48 & -32 & -12 & -47 & -47 & -40 & -44 \\
\hline HPU/PLS-PU/PVA & -41 & -31 & -12 & -44 & -45 & -39 & -35 \\
\hline $\mathrm{PVC}^{\mathrm{b}}$ & -45 & -29 & -09 & -29 & -50 & -37 & -50 \\
\hline
\end{tabular}

\footnotetext{
Determined by the separate solution method [26] ${ }^{\mathrm{b}}$ From Ref 19
} 


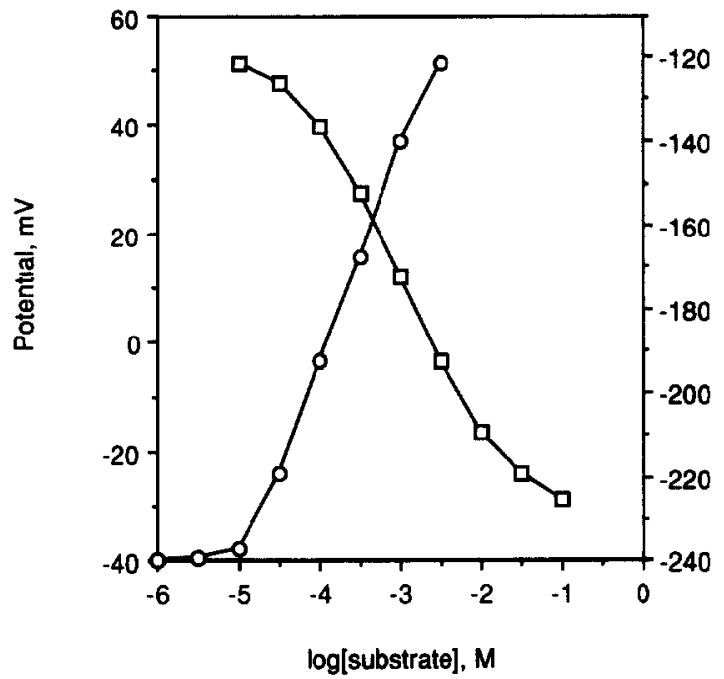

Fig 6 Calibration curves for $(O)$ adenosine electrode prepared by immobilizing adenosine deamınase through one-step glutaraldehyde method on $\mathrm{NH}_{4}^{+}$-selective asymmetric membranes, ( $\square$ ) urea electrode by covalently attaching urease through one-step glutaraldehyde method on proton-selective asymmetric membranes

In practice, both reactions can be detected by either monitoring $\mathrm{pH}$ changes or $\mathrm{NH}_{4}^{+}$lons generated In the present studies, the use of the proton-selective membrane was restricted to the urea/urease system, whlle both $\mathrm{ADA}$ and urease were immobilized on the ammonium selective asymmetric membranes

Enzyme immobilization was achieved by covalently attaching the enzymes to the amine groups avallable on the surface of the membrane through glutaraldehyde crosslinkıng reactions With twostep glutaraldehyde method, a monolayer of enzyme is immobilized, while one-step glutaraldehyde method results in multilayers of enzymes due to the crosslınking of enzyme molecules This usually yields greater enzyme loading [5]

A typical calıbration curve for an adenosine electrode prepared by immobilizing ADA on the asymmetric $\mathrm{NH}_{4}^{+}$-selective membrane using the one-step glutaraldehyde method is shown in Fig 6 The linear response range is from $10^{-5}$ to $3 \times 10^{-2} \mathrm{M}$ of adenosine with a slope of $48 \mathrm{mV}$ per decade Response times are on the order of $60 \mathrm{~s}$ to reach steady-state potential It should be noted that electrodes in which the asymmetric membrane was treated with enzyme, but no glutaraldehyde, also yield significant adenosine response (not shown) This observed response is due to non-specifically adsorbed ADA, presumably via 1on-exchange reactions with protonated amino groups of the polylysine within the outer HPU layer While the response of these latter electrodes can be elıminated by soaking the electrode in $4 \mathrm{M}$ of $\mathrm{MgCl}_{2}$ (to dissociate the adsorbed enzyme), the response of the glutaraldehyde treated enzyme electrodes remains the same after such treatment Indeed, adenosine electrodes prepared in this way can last for at least one month, with little loss in response slope or detection limits

Urea sensors based on pH-selective asymmetric membranes were also tested For such biosensors, the thickness of the outer HPU layer was found to be critically important with regard to the magnitude of the potentiometric response to urea observed By decreasing the total amount of the outer HPU/PLS layer (to $5 \mu \mathrm{m}$ ), optımum response in terms of sensitivity is observed It is believed that the thinner outer membrane keeps the enzyme layer closer to the hydrophobic ionselective detector layer (inner PU/PVA) so that rapid diffusion of protons into the bulk solution does not dimınish surface steady-state $\mathrm{pH}$ changes A typical calibration plot for a urea sensor based on the proton-selective asymmetric membranes is also presented in Fig 6 The slope is $298 \mathrm{mV}$ per decade with the dynamic range of $10^{-4}$ to $10^{-2} \mathrm{M}$ of urea Naturally, as with any enzyme electrode based on $\mathrm{pH}$ detection, sens1tivity is highly dependent on the buffer capacity of the sample medium [30] The response time to reach $95 \%$ of the steady-state potential is about 3 min Urea sensors based on the $\mathrm{NH}_{4}^{+}$-selective asymmetric membranes exhibit much higher response slope (56 mV per decade) and shorter response time (in seconds) when compared to those based on proton-selective membranes (see below)

\section{Response of mucrofabricated enzyme-electrodes}

When urease is immobilized on the surface of the asymmetric ammonium selective membrane cast onto the solid-state device shown in Fig 2 
(using two-step glutaraldehyde), the resulting biosensor responds rapidly and selectively toward urea (see Fig 7) Typical calibration curves for this device show a linear relation between the e $\mathbf{m} f$ and the logarithm of urea concentrations in the range of $10^{-5}-10^{-2} \mathrm{M}$ with slopes of 55-56 $\mathrm{mV}$ per decade This near-Nernstian slope and wide dynamıc measuring range suggests that high enzyme loading has been achieved on the surface of the asymmetric membranes [5] In the case of solid-state adenosine sensors prepared in the same manner (with immobilized ADA), the high slopes and detection limits remain essentially constant during one month of contınuous operation These results support previous claims regarding the very tight adhesion of the plastıcized PU/PVA/ 1onophore membranes to silicon nItride and silver epoxy surfaces [21] Indeed, had the membrane lifted around the edges, leakage of electrolyte would have shorted the membrane and elıminated any potentiometric ion or substrate response

It should be noted that each of the films used to construct the solid-state biosensor, startıng with the silver epoxy layer, can be screen printed for mass fabrication purposes In addition, the size and number of sensing regions per unit area of the slicon wafer can be varied While the above results have been obtained with single sensing sites on relatively large chips $(08 \mathrm{~cm} \times 10 \mathrm{~cm}$, with polymer membrane sensing area of $02 \mathrm{~cm}^{2}$ ), it is envisioned that an array of biosensing sites on the same size chip can be readily achieved using screen printed asymmetric membranes and site-directed photormmobilization of enzymes onto to the highly amınated HPU/PLS layers

In summary, a new asymmetric membrane system with improved surface properties for development of conventional and solid-state type potentıometric biosensors has been described The potentiometric ion response of this new asymmetric membrane is essentially the same as the base PU/PVA membrane as well as the conventional PVC membranes At the same time, the amine functional groups on the membrane surface can be used advantageously for covalently attachment of bioreagents While used here to construct enzyme electrodes for adenosine and urea, it is likely that other bioreagents including intact cells, antıbodies, etc, could be incorporated/attached to the outer PU/PLS layer to fabricate a variety of other biosensors (including single use devices) With the advantage of good adhesion to silicon wafer surfaces, this polyurethane asymmetric

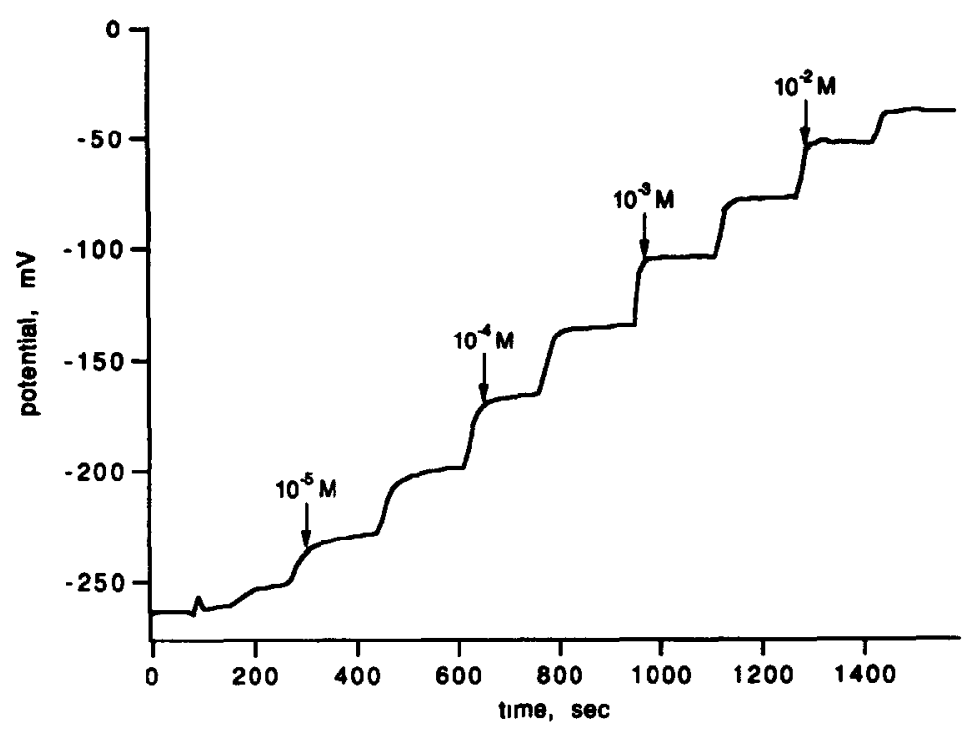

Fig 7 Dynamic potentiometric response of urea solid-state sensor based on $\mathrm{NH}_{4}^{+}$-selective asymmetric membrane 
membrane is a very promising candidate for use in constructıng varıous solıd-state biosensing devices

This work was supported by a grant from the National Science Foundation (ECS-8915497)

\section{REFERENCES}

1 M A Arnold and M E Meyerhoff, CRC Crit Rev Anal Chem, 20 (1988) 149

2 G G Gulbault, Analytical Uses of Immobilized Enzymes, Marcel Dekker, New York, 1984

3 J Janata, Principles of Chemical Sensors, Plenum Press, New York, 1989

4 F W Scheller, R Hintsche, D Pfeiffer, F Schubert, K Riedel and R Kindervater, Sensors Actuators, B4 (1991) 197

5 P W Carr and LD Bowers, Immobilized Enzymes in Analytical and Clınical Chemıstry, Wley-Interscience, New York, 1980, Chap 5

6 G G Gulbault and G Nagy, Anal Chem, 45 (1973) 417

$7 \mathrm{~K}$. Yasuda, H Miyagı, Y Hamada and Y Takata, Analyst, 109 (1984) 61

$8 \mathrm{G} \mathrm{S}$ Cha and ME Meyerhoff, Electroanalysıs, 1 (1989) 205

9 G S Cha and M E Meyerhoff, Talanta, 36 (1989) 271

$10 \mathrm{~J}$ Anzal, M Shımada, T Osa and C Chen, Bull Chem Soc Jpn , 60 (1987) 4133

11 I Karube, in R D Schmid, G G Gulbault, I Karube, H -L Schmidt and L B Wingard (Eds), Biosensors International Workshop, VCH, Weinheim, 1987, pp 155-163

12 M Gotoh, E Tamiya and I Karube, J Membrane Sc1, 41 (1989) 291
13 F Gardies, N Jaffrezıc-Renault, C Martelet, H Perrot, J M Alleton and S Alegret, Anal Chim Acta, 231 (1990) 305

14 R Hintsche, B Moller, I Dransfeld, U Wollenberger, F Scheller and B Hoffmann, Sensors Actuators, B4 (1991) 287

15 Y Hanazato, M Nakako, S Shiono and M Maeda, IEEE Trans Electron Dev, 36 (1989) 1303

16 S A. Rosario, G S Cha, M Trojanowicz and M E Meyerhoff, Anal Chem , 62 (1990) 2418

17 W Matuszewsk,, S A Rosano, ME Meyerhoff and M Trojanowicz, Anal Chem, 63 (1991) 1906

18 S A Rosario and M E Meyerhoff, Anal Chım Acta, 258 (1992) 281

19 S C Ma, NA Chanıtakıs and ME Meyerhoff, Anal Chem , 60 (1988) 2293

20 S C Ma and ME Meyerhoff, Mikrochım Acta, 1 (1990) 197

21 G S Cha, D Liu, ME Meyerhoff, H C Cantor, A R Midgley, H D Goldberg and R B Brown, Anal Chem , 63 (1991) 1666

22 G Iono and G Catapano, J Membrane Scı, 22 (1985) 317

23 K. Mosbach, Methods Enzymol, 135 (1987) 240

24 W D Potter, US Pat, 4,534,355 (1985)

25 P Schulthess, Y Shıo, H V Pham, E Pretsch, D Ammann and $W$ Simon, Anal Chım Acta, 131 (1981) 111

26 G G Guilbault, R A Durst, M S Frant, H Freiser, E H Hansen, T S Light, E Pungor, G A Rechnitz, N M Rice, T J Rohm, W Simon and J D R Thomas, Pure Appl Chem, 48 (1976) 127

27 W E Morf, The Principles of Ion-Selective Electrodes and of Membrane Transport, Elsevier Amsterdam, 1981

28 P Cuatrecasas, J Biol Chem, 245 (1970) 3059

29 X Ma, S F Mohammad and S W Kım, J Collord Interface Sc1 , 147 (1991) 251

30 R M Ianniello and A M Yacynych, Anal Chim Acta, 146 (1983) 249 